Marquette University

e-Publications@Marquette

College of Education Faculty Research and

Publications

Education, College of

$1-1-2010$

\title{
Are We "Reading the World"? A Review of Multicultural Literature on Globalization
}

Melissa L. Gibson

Marquette University, melissa.gibson@marquette.edu

Accepted version. Multicultural Perspectives, Vol. 12, No. 3 (2010): 129-137. DOI. (C) 2010 Taylor \& Francis Ltd. Used with permission.

Melissa L. Gibson was affiliated with the University of Wisconsin-Madison at the time of publication. 


\title{
Marquette University
}

\section{e-Publications@Marquette}

\section{Education Faculty Research and Publications/College of Education}

This paper is NOT THE PUBLISHED VERSION; but the author's final, peer-reviewed manuscript. The published version may be accessed by following the link in th citation below.

Multicultural Perspectives, Vol. 12, No. 3 (July/September 2010): 129-137. DOI. This article is (C Taylor \& Francis and permission has been granted for this version to appear in e-Publications@Marquette. Taylor \& Francis does not grant permission for this article to be further copied/distributed or hosted elsewhere without the express permission from Taylor \& Francis.

\section{Are We "Reading the World"? A Review of Multicultural Literature on Globalization.}

\author{
Melissa L. Gibson \\ University of Wisconsin, Madison, WI
}

\section{Abstract}

Given its commitment to "reading" the social context, how is multicultural education accounting for the shifting context of our globalized world? A conceptual review of multicultural journals reveals limited engagement. However, a more sustained analysis could fuel re-articulations and contestations of the purpose of education in the 21 st century.

\section{Introduction}

Given its commitment to "reading" the social context, how is multicultural education accounting for the shifting context of our globalized world? A conceptual review of multicultural journals reveals limited engagement. However, a more sustained analysis could fuel re-articulations and contestations of the purpose of education in the 21st century.

In his vision of transformative education, Paolo Freire (2005) argues that "reading the world"-"the comprehension of objects, tak[ing] place in the domain of day-to-day life" (p. 35)-is as vital for developing critical consciousness as "reading the word." The relationship between social context and 
book learning is at the heart of transformative education, or "education as the practice of freedom" ([22], p. 81): "Knowledge emerges only through invention and re-invention, through the restless, impatient, continuing, hopeful inquiry human beings pursue in the world, with the world, and with each other" ([22], p. 72). The act of knowing the world is inseparable from the act of transforming the world.

This commitment to "reading the world" is at the heart of critical and multicultural education for social justice. For example, critical multicultural educators argue that learning to critique one's social context and the political moment are central to furthering the democratic project of "thickening" our currently "thin democracy," which limits citizens to the tasks of "voting and buying" ([ 3] , p. 12). Likewise, developing critical consciousness, promoting a pluralistic and thick democracy, and "reading" the social context are all central tenets of multicultural education ([ 8]; [26]; [38]; [45]; [57]). How, then, is this form of socially transformative education-multicultural education for social justice-understanding our context of globalization?

From popular media and campaign slogans to calls for educating children for global competition, globalization is ever-present in the 21st century. In the popular media, globalization is characterized largely by the expansion of free trade, the spread of capitalist economies, and the growth of technology ([29]; [55]); in the critical literature, it is described as the newest form of neo-liberal imperialism ([ 9]; [15]; [17]). However, as both [55] and [51] argue, there are actually a multitude of globalizations, ranging from cultural and technological exchange to neo-liberal expansion to increased transnational migrations, with most of these globalizations finding their roots in prior centuries' imperialism. In this paper, the process of globalization is defined by "increased economic, cultural, environmental, and social interdependencies" as well as "new transnational financial and political formations arising out of the mobility of capital, labor, and information, with both homogenizing and differentiating tendencies" ([16], p. 33). Globalization is also characterized by the primacy of capital markets and by the reframing of "all social relations, all forms of knowledge and culture in terms of the market," with "[a]II human production and all sites of social intercourse, all services that a society establishes for the common good...potential targets for investment and profit making" ([40]). However, globalization is marked not only by increasing economic inequality but also by the increased possibility for transnational social protest.

Given this complex context of globalization and multicultural education's express commitment to "reading the world": (a) How is multicultural education engaging with the social context of globalization? (b) How is the dual context of increasing inequality and increasing possibility for global cultural exchange and social protest shaping the multicultural education discourse? (c) How can multicultural educators build on existing conversations around globalization, both within and outside of the field?

\section{Mode of Inquiry}

All three of these questions require an analysis of multicultural education's discourse, captured here by a conceptual review of scholarly journals within the field.[1] While there are multiple ways to capture a discourse, given the focus of the guiding questions-how multicultural education is engaging with 
globalization, how it is changing in light of this context, and how it can build on existing conversations-conducting this review served several purposes.

First, peer-reviewed journals are a widely recognized forum for scholarly engagement. They are a common way of representing a field's inquiry, albeit an incomplete one, in part because they frequently omit practitioners' perspectives. Second, while the depiction of peer-reviewed journals as the sole representation of a field is rife with bias and politics ([4]; [36]), that bias and those politics are central to this inquiry. How is the field critically and "officially" engaging with the context of globalization? How is it self-constructing and defining the parameters of its own discourse? Are questions about globalization deemed a worthy scholarly topic? By specifically selecting multicultural journals, I am focusing on researchers who self-identify as working within the bounds of multicultural education and who are participating in the field's self-construction. I have not, however, tried to include all voices or canonize "The" conversation-no review can be exhaustive, and all reviews are situated and perspectival ([ 7]; [39]; [41]).

I have examined the leading peer-reviewed journals in multicultural education (Equity and Excellence, Multicultural Perspectives, Multicultural Education, International Journal of Multicultural Education) from 2000 to the present. Articles were selected if they included globalization in the title, abstract, keyword, or body. 2000 was chosen as the lower time boundary because it marks the new millennium: Globalization is firmly a part of our lived experiences and our sociopolitical lexicon in the 21st century. Certainly, one could look farther back in history at the genesis of globalization-reaching as far back as the imperialist moves of earlier centuries - but for this review, I am concerned with scholarship situated in a widely recognized era of globalization.

These peer-reviewed journals are largely-though not exclusively-written by academic scholars in the American context. Therefore, two other publications were included in order to capture a wider group of multicultural educators: (1) Rethinking Schools, a non-peer-reviewed periodical written by teacherpractitioners explicitly concerned with social justice, multiculturalism, and critical educational practices; and ( 2) Intercultural Education, an international, peer-reviewed journal concerned with many of the same core issues as American multicultural education. By including these contrasting publications, I am hoping to expand our understanding of what a conversation about critical education and globalization might become.

\section{Defining Multicultural Education}

There are multiple instantiations of multicultural education, from superficial "food, fairs, and festivals" approaches to neo-conservative appropriations ([ 8]; [10]; [19]; [56]). I am, however, specifically concerned with multicultural education for social justice ([45]), or "education that is multicultural and social reconstructionist" ([57]), which is explicitly concerned with restructuring schools, teaching, and curriculum to equitably meet the unique needs of racially, linguistically, physically, and socioeconomically diverse learners and ultimately promoting social justice ([ 8]; [28]; [45]; [54]; [29]). Multicultural education for social justice is a framework that recognizes and values the diversity of the United States, promoting pluralistic education and democracy; it is a reform movement advocating structural, systemic change of American education; and it is a process of behaving and thinking that promotes equity and justice through anti-biased, anti-racist teaching. 


\section{Is Anybody Out There? A Review of the Literature}

Based on multicultural education's explicit commitment to social transformation and its pedagogies emphasizing the study and critique of the social context, one might expect a rich conversation among multicultural educators analyzing globalization. After all, as manifested in the simultaneous consolidation and diffusion of global capital, globalization is seen as linked to increasing inequality within and between nations ([ 9]; [15]; [27]). In addition, as linked to increased global competition for jobs, knowledge, technology, and resources, globalization is frequently used as a justification for current neo-liberal reforms in schools ([29]; [43]). These globalized and neo-liberal educational reforms frequently demonize the very pluralistic and multicultural communities that critical educators cultivate. Immigrants, for example, are constructed as a danger to our nation-state's survival in a globalized economy-yet there is little acknowledgement of the role that globalization (particularly transnational trade agreements) play in the patterns of immigration in the United States.

Both social and educational inequity are of central concern to multicultural education, as is crosscultural exchange, another facet of globalization ([59]). Any multicultural "reading of the world" that doesn't attend to these forces would be incomplete. How surprising, then, that multicultural education, as represented in these peer-reviewed journals, engages in only limited ways: In the eight years of publication of these four journals, there are a total of only seven articles mentioning globalization.

\section{Globalization as an Unquestioned Context}

In four articles, globalization is mentioned briefly as either (a) the reason for increased diversity and cultural hybridity due to increased global migrations and cultural exchange (Gallagher-Guertsen, 2007; [25]; [33]); (b) the source of increased technology ([ 1]); or (c) the changing political and economic context ([25]). Globalization is given no more than a paragraph, and often only a single sentencealthough, to be fair, it is not the central concern of these four articles. It remains, however, an important context for the advancements to multicultural education that these articles put forward, an important context that is largely left undefined and uncritiqued.

For example, [33] argues that culturally relevant pedagogy needs to expand its understanding of culture from a static, singular vision (e.g., African American culture, Latino culture) to one that can account for the hybrid identities of urban youth, identities shaped by globalized migrations and exchanges of culture that transcend physical markers of difference. While Irizarry's study shows how one teacher uses hybrid identities to teach in relevant ways, it does not problematize the context that has produced these identities. How might this teacher's culturally relevant pedagogy have been enhanced by a critique or discussion of the very forces that have produced this cultural exchange and hybridity?

[1] describes how his courses on multicultural education are enhanced by technology. He discovered serendipitously that online courses were actually the perfect forum for these topics, as some of the interpersonal conflicts that arise when tackling issues such as white privilege were abated. In contextualizing his work, Akintunde attributes the rise in instructional technology to the double-sided forces of globalized capitalism: "[A]s we grapple with the notion that technology is just as much a product of social inequality as a conduit through which we can address such an issue, it becomes 
incumbent on us to ensure that as the debate rages we are using the technology to its best advantage" (p. 44). Given his acknowledgement of the role that rapidly multiplying technologies play in magnifying white privilege, how is he engaging his students in a critique of this issue? We learn how globalization is methodologically changing his practice; how is it changing his work conceptually and theoretically?

Gallagher-Guertsen (2007) expands the multicultural analysis of privilege and oppression to include the linguistic privilege granted to speakers of non-accented Standard English. Her article sets forth not a theorization of practice but a documentation of the way that linguistic privilege rears its head in education: "Over time, dominant groups have assigned a particular status to languages and often place English at the top of their lists. The unequal status afforded different languages can translate into troubling practices.... It is important to understand our belief systems are how we act unconsciously toward students who are learning standard English" (pp. 41-42). Gallagher-Guertsen sees globalization as a justification for the dismantling of linguistic hierarchies: "Given the rapid globalization of the world that brings people and their cultures and languages into contact, classification of languages/cultures on a hierarchical scale that punishes people for 'difference' does not suffice" (p. 41). Here, GallagherGuertsen touches on the contradictory facets of globalization(s). How might her analysis of privilege be enhanced by an analysis, rather than a reference, of these dichotomous forces?

Finally, [25] explores how Border Pedagogy frames her teacher preparation work in the San Diego/Tijuana border region. She describes the aims of Border Pedagogy as "creating a means by which to cross borders, both physical and conceptual ...help[ing] participating teachers, including student teachers, 'to link broader political, ideological, and social issues with the concrete realities of schools. Teachers who embody these orientations will intervene in the lives of their students so as to help construct with them futures that are personally rewarding, socially responsible, and morally compelling"' (p. 4; quoting Beyer, 2001, p. 156). This pedagogy understands the border as a zone indelibly transformed by globalized relationships between nations; therefore, Border Pedagogy educators will "find themselves interpreting key roles in the unfolding drama of globalization" (p. 4). While Garza goes further than other authors in proposing that globalization is a central concern for socially transformative educators, she neither problematizes this context herself nor does she discuss how "interpreting the unfolding drama of globalization" is impacting her students' teaching and identities. What is the unfolding drama? How is it affecting the border region? How are teachers "reading the world" of globalization with their students in order "to help construct with them futures that are personally rewarding, socially responsible, and morally compelling?"

\section{Critiquing Globalization}

The remaining three articles engage far more substantively and centrally with globalization. These articles (a) detail a critical pedagogy analysis of globalization ([44]), (b) offer a justification and framework for critically teaching about globalization ([55]), and (c) argue for the explicit and sustained inclusion of globalization in teacher education ([32]). Unlike the previous articles, these three all define and critique globalization, and they make explicit connections between globalization and classroom practice.

[44] conducted an in-depth interview with critical educator Peter McLaren on the connection between critical pedagogy and the rise of global capitalism. In it, McLaren explicitly names globalization as an intensification of earlier forms of imperialism, with "the concept of globalization...effectively 
replac[ing] the term imperialism in the lexicon of the ruling elite for the purpose of exaggerating the global character of capitalism as an all encompassing and indefatigable power that apparently no nation-state has the means to resist or oppose" (p. 8). Because of this, and because of globalization's role in intensifying inequality and racism, McLaren sees the role of critical educators as fighting against globalization in order to install social justice, or a socialist economic system, on a global scale. However, the bulk of this interview is devoted not to a discussion of education but to a critique of the exploitative actions of globalized capital. McLaren uses the idea of pedagogy broadly to describe the ways that we can learn from our social context and inform our political stances, urging educators to ask: "Is there a viable socialist alternative to capitalism? What would a world without wage labor be like? Without living labor being subsumed by dead labor? Without the extraction of surplus value and the exploitation that accompanies it" (p. 14)? While McLaren goes far deeper into an analysis of the context of globalization than the authors of the first set of articles, educational practice is more of a footnote than a focal point.

[55], on the other hand, asks, "[N]ot whether education will be influenced by globalization, but rather how" (p. 9). Given this inevitability, Sleeter sets out to name the multiple manifestations of globalization, to connect these manifestations to the premises of multicultural education, and to offer resources to $\mathrm{K}-12$ teachers. In this analysis, there are six commonly occurring metaphors for describing globalization in the US:

- the "global village" metaphor, which speaks to the interconnectedness of cultures and the increase in international migrations;

- $\quad$ the "military competition" metaphor, which speaks to what are perceived as post-Cold War global struggles between good and evil and for global dominance;

- the "network of interdependence" metaphor, which speaks to the world becoming an interconnected market where nations specialize in a niche of production, market demand dictates the flow of capital, and free trade is equated with free choice;

- the "McWorld" metaphor, which speaks to the rise of rampant, "big box" consumerism as a global culture;

- the "spaceship earth" metaphor, which speaks to the interconnectedness of earth's fragile ecosystems and the need for a systems approach to reducing the environmental impact of human actions; and

- the "neo-colonialism" metaphor, which speaks to the way that profit-driven market systems mimic the patterns of racism, domination, and exploitation of colonial relationships of years past.

These metaphors are frequently used to justify and explain globalization. Metaphors that are less critical-"global village," "military domination," and "networks of interdependence"-are given far more attention in school curricula than are those that challenge the effects of globalization. These three metaphors therefore "converge into an overall narrative: The world is interdependent, although made up of independent and competing nations. Western ideas and systems represent the culmination of human cultural evolution; in global competition these ideas and systems will eventually prevail" (p. 5). This narrative ignores power relations, which are at the heart of modern globalization. 
To counter this dominant narrative, Sleeter points teachers to critical globalization resources (e.g., [15]), which recast globalization in terms of the other metaphors-"McWorld," "spaceship earth," and "neo-colonialism." These competing narratives of globalization have important consequences for education: "Increasingly, schools are losing a vision of education for public good and shifting toward education for private consumption and the needs of transnational corporations. This means that, increasingly, schooling is helping to serve global imperialism. There is an alternative, and there are now teaching resources to help develop it. We can begin by rethinking today's globalization" (p. 9).

[32]'s discussion of how they teach globalization extends Sleeter's challenge to the teacher education arena. Like Sleeter and McLaren, Hytten and Bettez also see "[t]eaching about globalization [as] integral to helping us to reground education in a vision of democracy that balances individual rights and social responsibilities and that is predicated on what is best for all citizens in the world, not just a select few" (p. 178). By globalization, they specifically mean the fact that the world is increasingly interconnected in four primary arenas - technological, political, cultural, and economic. They are particularly concerned with the economic dimensions of globalization that prioritize profit at the expense of most other human and social needs: "Clearly this poses a threat to education for critical thinking and the cultivation of democratic values (e.g., looking out for the common good, balancing rights with responsibilities), which is an important enough reason that educators need to learn something about the processes, philosophy, and manifestations of globalization" (p. 173).

To counter this threat to democratic education, Hytten and Bettez describe how their teacher education work is grounded in Noddings' (2005) dimensions of global citizenship, in which citizens advocate for social and economic justice, protection of the Earth, cultural pluralism, and world peace. Global citizens are "committed to eliminating poverty, creating sustainable lifestyles, making wellinformed choices, and maintaining an ecology of interdependence. Such positions require not a valueneutral look at globalization but one that centralizes issues of justice and caring" (p. 175). To foster this kind of citizenship among pre-service teachers, Hytten and Bettez explicitly teach about globalizationits multiple dimensions, its connection to the local, and its danger to democracy-in order to challenge "our students' sense of themselves as good people in a basically fair and meritocratic world, not people who in many ways benefit from inequitable social relations, even if they are not individually responsible for them" (p. 176). This, they hope, will cultivate social justice commitments.

\section{Comparing Conversations, Finding New Directions}

These articles, as a representation of the scholarly discourse, lead to three primary critiques: (1) There is extremely limited engagement with globalization and its relationship to education, as evidenced by the few articles that deal with globalization at all; (2) When globalization is discussed, it is often as a taken-for-granted backdrop whose meaning and context is neither critiqued nor thoroughly discussed; and (3) When globalization is theorized and critiqued, education is not necessarily foregrounded in the larger sociopolitical discussion. Based on the way that the field represents itself in its peer-reviewed journals, it does not seem that globalization is an important element of the social context for multicultural education. 
However, the [55] and [32] pieces, which foreground both a critical analysis of globalization as well as a connection with pedagogy, offer an alternative means of engaging with globalization. This engagement as both a theoretical foundation and an area of curricular inquiry is also taken up by Rethinking Schools, a teacher-practitioner periodical that, since 2000, has alone published 12 articles documenting and arguing for the inclusion of globalization in K-12 classrooms ([ 6]; [14], [12]/b, [11]; [18]; [20]; [34]; Peterson, 2000/2001a/b; Rethinking Schools, 2002; Sokolower, 2006). This approach is also reflected in Bigelow and Peterson's (2002) classroom resource, Rethinking Globalization.

For example, [58], a high school history teacher, merges her theorizing about globalization with her actual classroom practice. Committed to providing her English language learners with high quality, critical curriculum, she chose to focus on globalization, generally, and-since all of her immigrant students were "experts" on migration-migration more specifically. Central to this instructional and curricular work was her theorizing about globalization. She offers to her students the following original definition of globalization:

More than ever before in history, there is one world economy. This pressure toward one world economy is called globalization. Globalization is the struggle for control of the earth's resources-natural resources, human resources, and capital resources. There are eight elements of globalization: Migration. Big companies are international companies. Resources are international. Free trade agreements. World Bank and International Monetary Fund (IMF). Sweatshops. Environmental problems. Increased communication among people-the basis for resistance.

Similarly, Peterson ([48]) describes how he uses storytelling, problem posing, and case studies to prod his fifth graders to critically think about global inequality. The root of his approach lies in two foundational understandings. First, teaching about globalization is similar to teaching about multicultural education: "They need to be both woven throughout the curriculum and highlighted in specific lessons. This approach is necessary in part to find the time to teach about the issues, given all that elementary teachers are expected to cover. But also I find that an integrated approach helps motivate students and teaches them that these are central issues that cannot be dealt with in one or two activities." Second, he worries that traditional conversations about globalization "can feed into the inherently condescending attitude that people in the US have all the answers, that people in 'developing' countries are somehow inferior or less than human, and that assumes that the role of those in the US is to 'help the less fortunate."' These understandings, grounded in his classroom practice and his understanding of the scholarly literature, frame his pedagogical choices about globalization.

Both Peterson and Sokolower-as well as the other teacher-practitioners writing in Rethinking Schools-embody a praxis largely missing in the scholarly discourse, merging their reflections on and theorizing about the sociopolitical context of globalization with actual curriculum and classroom practice. In addition to tying theory about globalization to actual teacher practice, Rethinking Schools regularly critiques over-simplified understandings of globalization, particularly as they shape public education (Bigelow, 2002; [20]; Rethinking Schools, 2002). The authors in Rethinking Schools directly challenge the dominant narrative of interdependence, American superiority, and human advancement that [55] describes as the over-arching understanding of globalization in the public discourse. Instead, these authors focus on the neo-colonial and neo-liberal foundations of globalization: they analyze the 
connection between globalization and global migration, cultural erasure, and global exploitation. However, they simultaneously push their students to also see the opportunities for trans-national cooperation, resistance, and positive interdependence. Their critical analysis of globalization in the classroom context becomes a springboard for social action and social change.

This level of problematization and analysis was missing in many of the scholarly articles. The teacherpractitioners do not simply build curriculum from a taken-for-granted globalized context; rather, they critique, problematize, and analyze that very context. Perhaps Compton (2005), the president of the National Union of Teachers in England, summarizes Rethinking Schools' understanding of the implications of globalization for democratic education best:

[T]eachers and teacher unions have it in their power to reverse the drive towards privatization and to fight for proper publicly funded education. And, as teachers, we have an added bonus: Corporations can try all they like to control education to produce unquestioning, quiescent workers, but we have the ability to ensure that we educate young people to develop a proper understanding of the world and to make their voices heard. In our positions as teachers and teacher trade unionists, we can and must exercise our historic responsibility to the children of the world and the teachers of the future. We can ensure that education will enable children to live full and rich lives through properly funded public education systems.

Finally, the conversation in Intercultural Education also points to a new avenue for multicultural educators to engage with globalization. In all three of these articles ([21]; [31]; [35]), the authors challenge taken-for-granted notions of globalization as a neutral or beneficent force, particularly as this force defines education in capital's interest:

Instead of utilizing the potential contribution of teachers to enhance the best interests of society, education is seen as a handmaiden to strengthen the narrow interests of the market. In other words, learning and knowledge are replaced by schooling, and education with training. Teachers and their profession are neither cherished nor lauded, but instead chastised. The disenchantment and disenfranchisement of large numbers of groups is, in its wake, debasing the role of education ([31], p. 128).

[21] takes this critical analysis of the relationship between globalization and education one step farther. He argues that the context of globalization is central to understanding intercultural education, both in terms of its current shortcomings and what it can become. He describes current manifestations of intercultural education as grounded in a politically neutral understanding of culture that is premised on unrealistic and normative ideas of inclusiveness and that rarely transcends national borders. However, in intercultural education's concern with diverse peoples in Europe-diversity that is compounded by increasing economic and political migrations-the field is inherently impacted by globalization, as "unpicking the self-interest and blatant militarism in Washington, Moscow, and Jakarta that underpin the 'war on terror,' and the relation of these to the different patterns of colonialism, decolonization, and neo-colonialism is central to the enterprise of intercultural education" (p. 250).

Given globalization's centrality to what intercultural education can become as well as the field's current lack of engagement, Coulby calls for "a contextual audit of the content and aims of 
intercultural education" (p. 258), for more overt politicization, and for more attention to contemporary patterns of neo-colonialism:

It is not only the immediate context but the wider framework that is too often under-theorized and effectively de-politicized. Demographic movement is at the centre of much (though by no means all) intercultural education. Demographic movement results from national, and increasingly international, economic, political, and cultural forces. These forces may be expressed, for the sake of brevity, as globalization. Other forms of inter-group differentiation and inequality (not necessarily connected with demographic movement) such as exploitation, imperialism, ethnic cleansing and neo-colonialism also operate within a wider social context which may be characterized as globalization. If the educational experiences of Kosovo refugee children in South London, say, are to be understood, these contextual aspects cannot be ignored. To put it another way: to the extent to which the context of globalization is overlooked, intercultural education will have de-politicized its subject matter and, despite its progressive normative position, it will ill-serve both its subjects and wider social understanding. To depoliticize intercultural education is to cut it off from many of the possibilities of political action and redress. Intercultural education needs to develop a discourse which can move from the global forces that have brought NATO troops into Pristina to the intricacies of a teenage boy learning English in the prejudicially framed school and society of London (p. 249).

His indictment of intercultural education could just as well be made at multicultural education scholarship, where there is scant engagement with globalization. By ignoring this context for education, a context that impacts and shapes the very issues of diversity and inequality with which multicultural education is centrally concerned, the field runs the risk of de-politicizing and making irrelevant its important and historic struggles for educational equity.

\section{Conclusion: Educational Importance \& Research Implications}

Globalization is an underexplored issue for multicultural scholars; engagement with globalization is often an uncritical acceptance of the taken-for-granted context. The increasing inequalities and increasing possibilities of globalization seem to have had little impact on reframing the field. To keep multicultural education relevant in the shifting context of the 21st century, multicultural scholars must address globalization as an area of curricular inquiry and a site of sociopolitical and educational contestation.

In an era marked by the "primacy of property rights over human rights" ([53], p. 144) and an era of increasingly contested migrations, multicultural education for social justice has become even more necessary: promoting equality, justice, and human dignity for all, regardless of national or ethnic origin, can push back against the imperialist forces of globalization, forces that narrow the purpose of education. Globalization is, after all, characterized by the primacy of capital markets, regardless of the human costs. We see these tendencies within education, where conversations about schooling are increasingly framed in terms of capital's needs ([29]; [40]; [53]).

Multicultural education for social justice is a challenge to this vision of education and democracy. After all, it explicitly advocates education for self-realization, cultural understanding, "thick" democracy, and social transformation - the very antithesis of capital's construction of education. A deeper, more sustained analysis of globalization could, in fact, fuel broader rearticulations of the purposes of education in the 21st century. Unfortunately, the limited conversation currently taking place makes it 
appear as if the multifaceted forces of globalization in economics, politics, culture, technology, and the environment are depoliticized, when in fact these forces magnify inequality, exploitation, and racism. By remaining silent about globalization, multicultural education runs the risk of supporting the status quo.

One aspect that nearly all the articles touch on is globalization's impact on community and classroom diversity due to its impact on global migration. This emphasis within the multicultural literature makes sense. After all, multicultural education is primarily concerned with promoting pluralism in the classroom and in society as a whole. However, this emphasis also opens a door for multicultural educators not merely to critique but also to find cracks in our sociopolitical context through which to engage in counter-hegemonic struggles. There are, in fact, advantages to our global world-the interconnectedness of world citizens ([16]), the possibilities of cosmopolitanism to triumph over nativism ([ 2]; [47]), the internationalism of struggles for social justice ([ 3]; [42]) - spaces in which educators can promote pluralism and equality. As the teacher-practitioners in Rethinking Schools understand, globalization-despite its destructive forces-has also opened possibilities for transnational collaboration, protest, and social transformation. How might attending to this possibility transform classroom teaching for social justice? How might it broaden our understanding of social action and cultural relevance? How might these dual forces of increasing inequality and increasing possibility help us to reframe what multicultural education for social justice is? How might scholars of multicultural education reinvigorate their field by learning from the "wisdom of practice" ([37]; [52]) of multicultural teacher-practitioners who are already actively contesting and problematizing the dominant narratives of globalization? How might a richer "reading of the world" answer the oft-heard complaint, "But what does multicultural/social justice education actually look like?"

\section{References}

1. Akintunde, 0.2006. Diversity.com: Teaching an online course on white racism and multiculturalism. Multicultural Perspectives, 8(2): 35-45.

2. Appiah, K.2003. "Grounding human rights". In Michael Ignatieff: Human rights as politics and idolatry, Edited by: Gutmann, A.101-116. Princeton, NJ: Princeton University Press.

3. Apple, M.2006. Educating the "right" way: Markets, standards, God, and inequality, , 2nd ed, New York: Routledge.

4. Apple, M.1999. What counts as knowledge? The social production and use of reviews. Review of Educational Research, 69(4): 343-346.

5. Apple, M. and Buras, K.2006. The subaltern speak: Curriculum, power, and educational struggles., New York: Routledge.

6. Au, W.2000. Teaching about the WTO [Electronic version]. Rethinking Schools, 14(3)

7. Baker, B.1999. What is voice? Issues of identity and representation in the framing of reviews. Review of Educational Research, 69(4): 365-383.

8. Banks, J.2004. "Multicultural education: Historical development, dimensions, and practice". In Handbook of research on multicultural education, , 2nd edition, Edited by: Banks, J. and Banks, C.3-29. San Francisco: Jossey Bass.

9. Bauman, Z.2004. Wasted lives: Modernity and its outcasts., City: Polity Press.

10. Bennett, C.2001. Genres of research in multicultural education. Review of Educational Research, 71(2): 171-217. 
11. Bigelow, B.2002/2003. Rethinking globalization: Thinking in pictures [Electronic version]. Rethinking Schools, 17(2)

12. Bigelow, B.2002a. Defeating despair [Electronic version]. Rethinking Schools, 16(3)

13. Bigelow, B.2002b. Rethinking globalization: Teaching and organizing against sweatshops [Electronic version. Rethinking Schools, 17(1)

14. Bigelow, B.1999. Masks of global exploitation [Electronic version]. Rethinking Schools, 14(2)

15. Bigelow, B. and Peterson, B., eds. 2002. Rethinking globalization: Teaching for justice in an unjust world., Milwaukee: Rethinking Schools.

16. Blackmore, J.1999. Localization/globalization and the midwife state: Strategic dilemmas for state feminism in education. Journal of Education Policy, 14(1): 33-54.

17. Bourdieu, P.1998. Acts of resistance: Against the tyranny of the market., New York: The New Press.

18. Childs, S.2001. Questions are the answer [Electronic version]. Rethinking Schools, 15(4)

19. Cochran-Smith, M.2003. The multiple meanings of multicultural teacher education: A conceptual framework. Teacher Education Quarterly, 30(2): 7-26.

20. Compton, M.2005. We are the world [Electronic version]. Rethinking Schools, 19(3)

21. Coulby, D.2006. Intercultural education: Theory and practice. Intercultural Education, 17(3): 245-257.

22. Freire, P.2007. Pedagogy of the oppressed, , 30th anniversary edition, New York: Continuum.

23. Freire, P.2005. Teachers as cultural workers: Letters to those who dare to teach, , expanded edition, Boulder, CO: Westview Press.

24. Gallagher-Geurtsen, T.2007. Linguistic privilege: Why educators should be concerned. Multicultural Perspectives, 9(1): 40-44.

25. Garza, E.2007. "Becoming a border pedagogy educator.". Multicultural Education, 15(1): 2-7.

26. Gay, G.2000. Culturally responsive teaching: Theory, research and practice., New York: Teachers College Press.

27. Giroux, H.2006. Reading Hurricane Katrina: Race, class, and the biopolitics of disposability. College Literature, 33(3): 171-196.

28. Grant, C. and Agosto, V.2008. "Teacher capacity and social justice in teacher education". In Handbook of research in teacher education: Enduring questions in changing contexts, Edited by: Cochran-Smith, M. and Demers, K.176-200. London: Taylor and Francis.

29. Grant, C. and Grant, A.2007. Schooling and globalization: What do we tell our kids \& clients?. Journal of Ethnic and Cultural Diversity in Social Work, 16(3/4): 213-225.

30. Grant, C. and Sleeter, C. 2007. Turning on learning: Five approaches for multicultural teaching plans for race, class, gender and disability., New York: Wiley.

31. Gundara, J.2000. Religion, human rights, and intercultural education. Intercultural Education, 11(2): 127-136.

32. Hytten, K. and Bettez, S.2008. Teaching globalization issues to education students: What's the point?. Equity and Excellence in Education, 41(2): 168-181.

33. Irizarry, J.2007. Ethnic and urban intersections in the classroom: Latino students, hybrid identities, and culturally responsive pedagogy. Multicultural Perspectives, 9(3): 21-28.

34. Johnson, K.2004. Confronting child labor [Electronic version]. Rethinking Schools, 18(4)

35. Johnson, L.2003. The diversity imperative: Building a culturally responsive school. Intercultural Education, 14(1): 17-30.

36. Kennedy, M.2007. Defining a literature. Educational Researcher, 36(3): 139-147.

37. Ladson-Billings, G.1995a. "Multicultural teacher education: Research, practice, and policy". In Handbook of research in multicultural education, Edited by: Banks, J. and Banks, C.747-759. San Francisco: Jossey Bass.

38. Ladson-Billings, G.1995b. Toward a theory of culturally relevant pedagogy. American Educational Research Journal, 32(3): 465-491.

39. Lather, P.1999. To be of use: The work of reviewing. Review of Educational Research, 69(1): 2-7. 
40. Lipman, P.2001. Bush's education plan, globalization, and the politics of race. Cultural Logic, 4(1)Retrieved July 21, 2010 from http://clogic.eserver.org/4-1/lipman.html

41. Livingston, G.1999. Beyond watching over established ways: A review as recasting the literature, recasting the lived. Review of Educational Research, 69(1): 9-19.

42. Maran, R.1999. International human rights in the US. Social Justice, 26(1): 49-71.

43. Merriman, W. and Nicoletti, A.2008. Globalization and American education. The Educational Forum, 72: $8-22$.

44. Munoz, L.2002. The globalization of capital, critical pedagogy, and the aftermath of September 11: An interview with Peter McLaren. Multicultural Education, 10(1): 7-27.

45. Nieto, S.2000. Affirming diversity., New York: Longman.

46. Noddings, N.2005. Educating citizens for global awareness., New York: Teachers College.

47. Parker, W.2004. "Diversity, globalization, and democratic education: Curriculum possibilities". In Diversity and citizenship education: Global perspectives, Edited by: Banks, J.43-458. San Francisco: Jossey Bass.

48. Peterson, B.2000/2001a. Planting seeds of solidarity [Electronic version]. Rethinking Schools, 15(2)

49. Peterson, B.2000/2001b. Songs with a global conscience [Electronic version]. Rethinking Schools, 15(2)

50. Rethinking Schools. 2002. Educate for global justice: A key lesson from September 2001 [Electronic version]. Rethinking Schools, 17(1)

51. Santos, B.2002. "Toward a multicultural conception of human rights". In Moral imperialism: A critical anthology, Edited by: Hernandez-Truyol, B.39-60. New York: NYU Press.

52. Shulman, L.1987. Knowledge and teaching: Foundations of the new reform. Harvard Educational Review, 57: 1-22.

53. Sleeter, C.2008. Teaching for democracy in an age of corporatocracy. Teachers College Record, 110(1): 139-159.

54. Sleeter, C.2004. Critical multicultural curriculum and the standards movement. English Teaching: Practice and Critique, 3(2): 122-138.

55. Sleeter, C.2003. Teaching globalization. Multicultural Perspectives, 5(2): 3-9.

56. Sleeter, C.1995. "An analysis of the critiques of multicultural education". In Handbook of research on multicultural education. Edited by: Banks, J. and Banks, C.

57. Sleeter, C. and Grant, C.1999. Making choices for multicultural education: Five approaches to race, class, and gender, , 3rd edition, Upper Saddle River, NJ: Merrill Prentice Hall.

58. Sokolower, J.2006. Bringing globalization home [Electronic version]. Rethinking Schools, 21(1)

59. Suarez-Orozco, M. and Sattin, C.2007. "Wanted: Global citizens". In Educational Leadership.

\section{Footnotes}

1In defining my research as a "conceptual literature review," I am borrowing from Mary Kennedy's (2007) typology of scholarly literature reviews. Unlike a systematic literature review, which is focused on an empirical question ("To what extent does A contribute to B?") and attempts to gather all available literature in order to summarize what we already know, a conceptual literature review is concerned with "gaining new insights into an issue" (p. 139). This kind of review may be theoretical, historical, methodological, or integrative in nature. Conceptual reviews, rather than asking what we know empirically, set out to ask why we don't know more. To do that, however, conceptual reviews are equally concerned with conducting as exhaustive of a review as possible within the given parameters in order to most comprehensively reflect a field's body of knowledge. 
By MelissaL. Gibson

Reported by Author 